\title{
Covid-modulated emphysematous pyelonephritis against the background of a severe course of oxygen- dependent Covid pneumonia
}

\author{
A.I. Mukhomor, A.I. Zhelezko \\ Clinical hospital «Feofania»
}

Gas-forming kidney infectious lesion was first described in 1898 [7]. The following terms were used: renal emphysema, pneumonephritis. In 1962, it was proposed to designate a number of pathological processes that lead to the destruction of the renal parenchyma with gas formation, as emphysematous pyelonephritis (EP) [12].

$\mathrm{EP}$ is a rare form of acute purulent pyelonephritis caused by microorganisms that decompose glucose into acid and carbon dioxide, characterized by the development of an acute necrotizing process in the renal parenchyma. The disease is characterized by the accumulation of gas bubbles in the kidney tissues (in the kidney interstitium, its cavity or urinary system) and in the surrounding fiber.

Etiology and pathogenesis. The main causative agents of urinary tract infection in persons with EP are: Escherichia coli in $60-70 \%$ of cases, Klebsiella pneumoniae in 20-30 \% of cases, in other cases, bacteria of the following families: Acinetobacter, Proteus, Streptococcus and Pseudomonas, fermenting glucose with the formation of acid and gas accumulations of parapelvic, subcapsular or retroperitoneal localization. Wherein, gas is always visible in the renal parenchyma $[2,4,13]$. There are reports of infection with anaerobic microorganisms (Bacteroides fragilis and Clostridium septicum) and fungi (Candida and Aspergillus) [2].

Clinical picture. In $30 \%$ of patients, the disease begins acutely: chills suddenly increases, body temperature reaches febrile numbers $(+40$ $\circ \mathrm{C})$, tachycardia develops, in most cases motor agitation, nausea, sometimes turning into indomitable vomiting, are observed. Patients complain about general weakness, malaise, high body temperature, chills, severe back pain, dry tongue, decreased appetite. Often, the disease proceeds with manifestations of bacteriotoxic shock, while local symptoms are poorly expressed or they simply do not exist. The course of the disease in most cases is severe. The disease is accompanied by a sharp impairment of renal function and severe intoxication. EP is often complicated by renal vascular thrombosis and renal papillary necrosis. The process is usually one-sided. Women get sick more often than men $[1,2,4,5,14]$.

Diagnosis of EP is based on the data of urine bacteriological examination (detection of gas-forming microorganisms), urinary tract ultrasound diagnostics and X-ray examination. Bimanual palpation reveals an enlarged affected kidney. In most cases, EP is accompanied by an increase in sed rate, high leukocytosis, neutrophilia, hypochromic anemia. All patients have proteinuria, leukocyturia, bacteriuria, microhematuria. As a result of enzymatic decomposition of glucose into gas and acid by anaerobic microorganisms, urine becomes sharply acidic. Pneumaturia is very rare $[13,14]$.

Differential diagnosis is carried out with other acute diseases: acute appendicitis, cholecystopancreatitis, perforated stomach and duodenal ulcer.

A rare case of EP caused by parapsilosis Candida parapsilosis and Finegoldia magna was described (the first reported case of EP caused by Finegoldia magna) [8]. A 62-year-old man with diabetes mellitus (DM) presented with complaints of abdominal pain, dyspnea and nausea. The patient first noticed abdominal pain 3 weeks before going to the hospital; however, he avoided treatment for fear to get infected with severe acute respiratory syndrome, coronavirus 2 (SARS-CoV-2). This patient had a worsening condition and he died after surgery despite having an uncomplicated nephrectomy. The authors rightly suggest that delayed treatment due to avoidance behavior may contribute to higher mortality rates in patients with EP.

Researchers, revealed 2 types of EP, based on a retrospective analysis of the results of plain radiogra- 
phy, CT and ultrasound of the abdominal cavity and urinary system of 38 patients, which have a statistically significant difference in prognosis [14]: Type I, "dry type" of lesion, characterized by purulent-necrotic changes in the renal parenchyma, the presence of gas in the form of stripes or small bubbles, but in the absence of liquid accumulation; Type II - fluid accumulations in the kidney or perirenal fiber with large gas bubbles, gas in the collecting system of the kidney. The mortality rate $(69 \%)$ at EP Type I was higher than at EP Type II (18 \%). "Dry" type of EP (Type I) has a rapid course and a shorter disease duration from its onset to death $(\mathrm{p}<0.001)$, the mortality rate is $69 \%$ (at Type II - $18 \%$ ) [14].

Patient Z., 66 years. Admitted 12.12. 2020 with clinical symptoms of EP. In October-November of this year had covid-19 - pneumonia (Fig. 1, 2). MSCT of the kidneys and adrenal glands (Fig. 3). The adrenal glands and the right kidney are of normal size and shape. The urinary system is not dilated, no radiopaque calculi were found. The parenchyma of the left kidney is almost completely destroyed and fragmented. At the site of the anatomical location, as well as in the para- and perinephria - gas. In the upper third of the left ureter there is a calculus of $4 \mathrm{~mm}$ in diameter. Conclusion: CT signs are typical for left-sided EP.
Surgery of a liquid reservoir. In aseptic conditions, under ultrasound control, drainage of the perirenal collector on the left was performed, up to $20 \mathrm{ml}$ of bloody contents were obtained (Fig. 4). The drainage tube was fixed to the skin.

Microbiological culture of urine: $106 \mathrm{KUO}$ Klebsiella pneumoniae.

Surgery. Nephrectomy (Fig. 5).

Postoperative period: without features.

Comment. SARS-CoV-2 has a specific threedimensional spike protein structure that is characterized by strong binding affinity with angiotensin converting enzyme 2 (ACE2) receptors. Naturally, human cells expressing ACE2 can be target cells for SARS-CoV-2 [10]. Based on the definition of ACE2 expression, organs with a high risk of viral invasion were identified: heart, ileum, esophagus, bladder $(2.4 \%$ of ACE2-positive cells in the urinary bladder urothelium) and kidney (4.0\% of ACE2-positive cells in the proximal convoluted tubules). Exactly by this can explain the acute kidney damage that occurs in $0.1-29.0 \%$ of patients with COVID-19 [15].

All patients with polymorbidity have higher mortality risks in case of infection with COVID-19 [6]. SARS-CoV-2 uses ACE-2 receptors

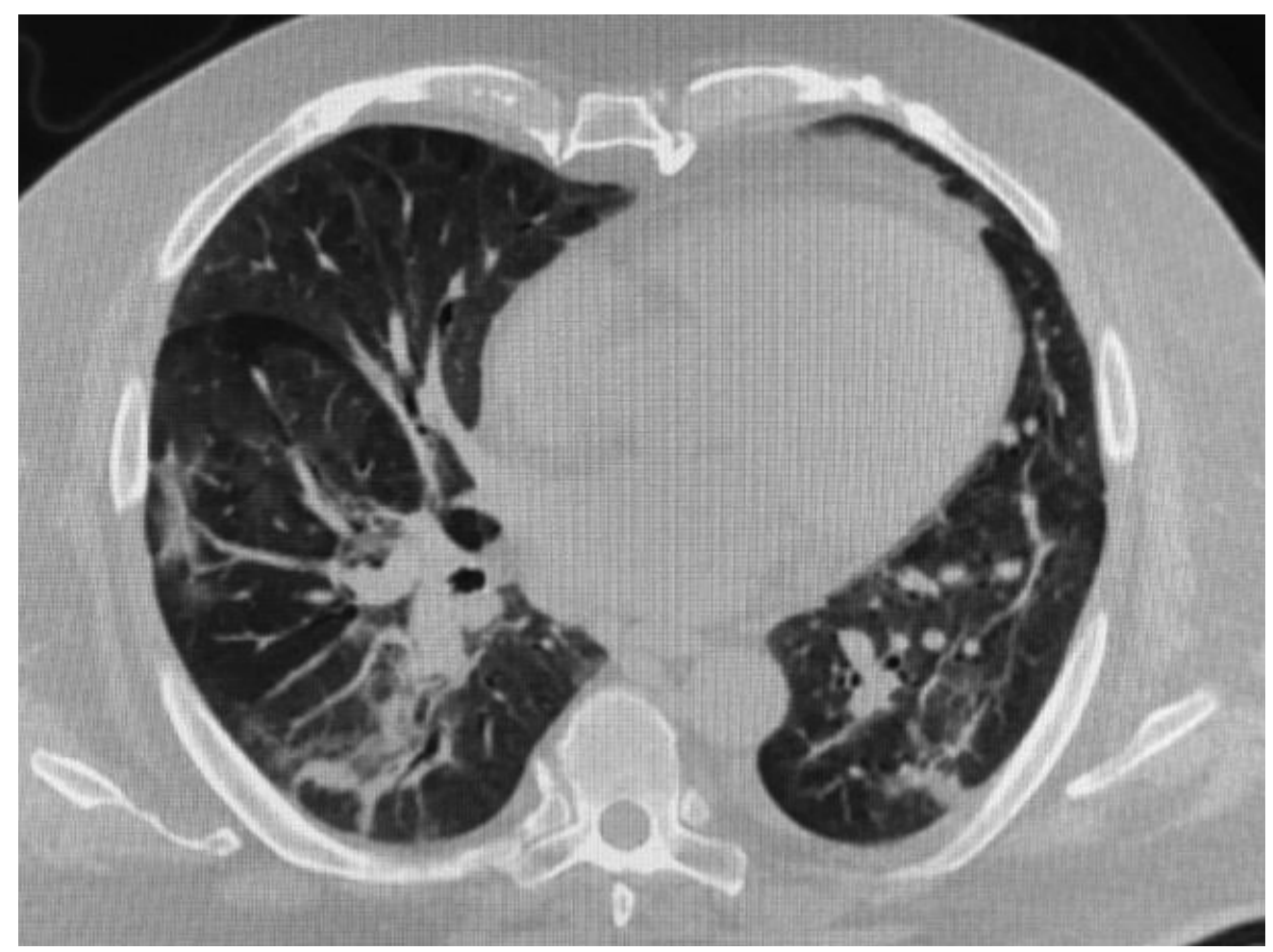

Fig. 1. MSCT. 5.11.2020. Lungs with signs of polysegmental covid pneumonia. 
found on the surface of host cells to enter inside the cell. Certain concomitant diseases are associated with strong expression of the ACE-2 receptor and higher release of proprotein convertase, which enhances viral penetration into host cells. Concomitant diseases lead the COVID-19 pa- tient into a vicious circle and are largely associated with significant morbidity and mortality.

Patients with COVID-19 with acute kidney injury have a high mortality rate (60-90\%) [11]. The mortality rate of patients with polymorbidity is presented in the table.

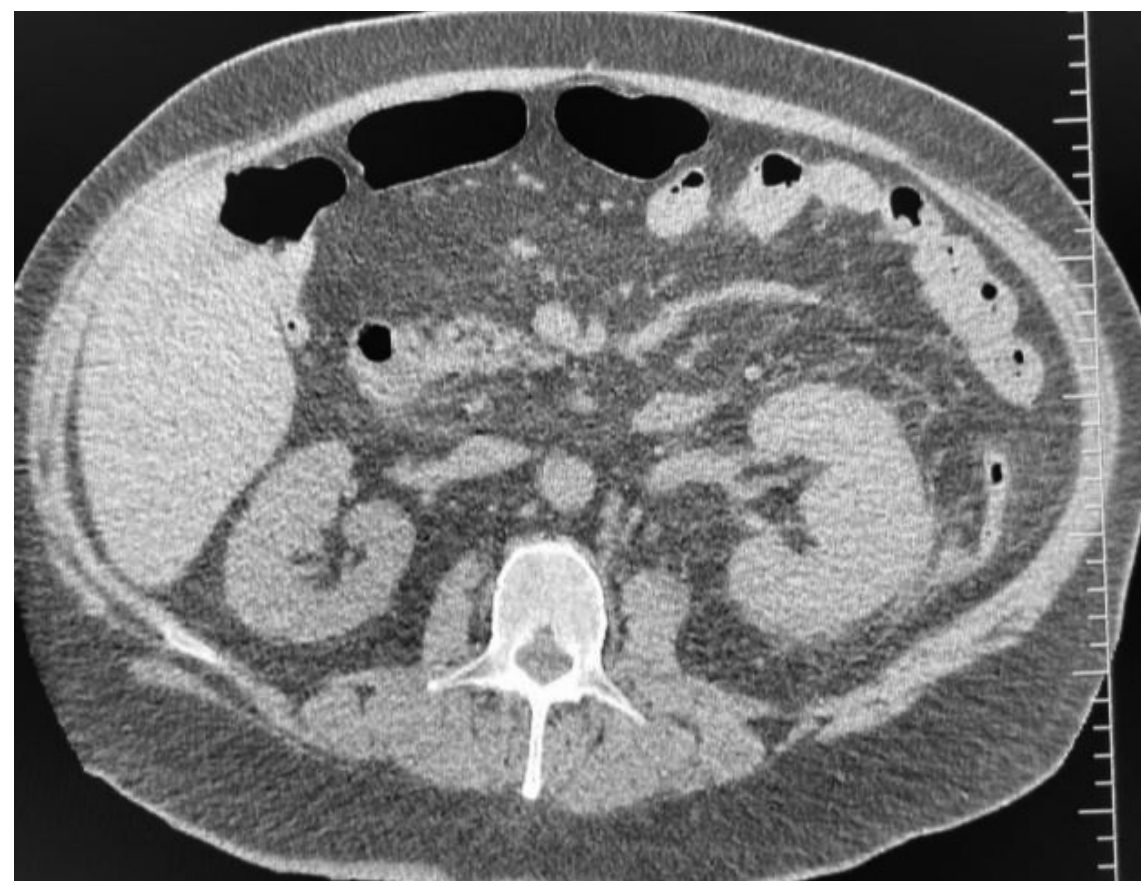

Fig. 2. MSCT. 5.11.2020. Kidneys without signs of pathological changes.

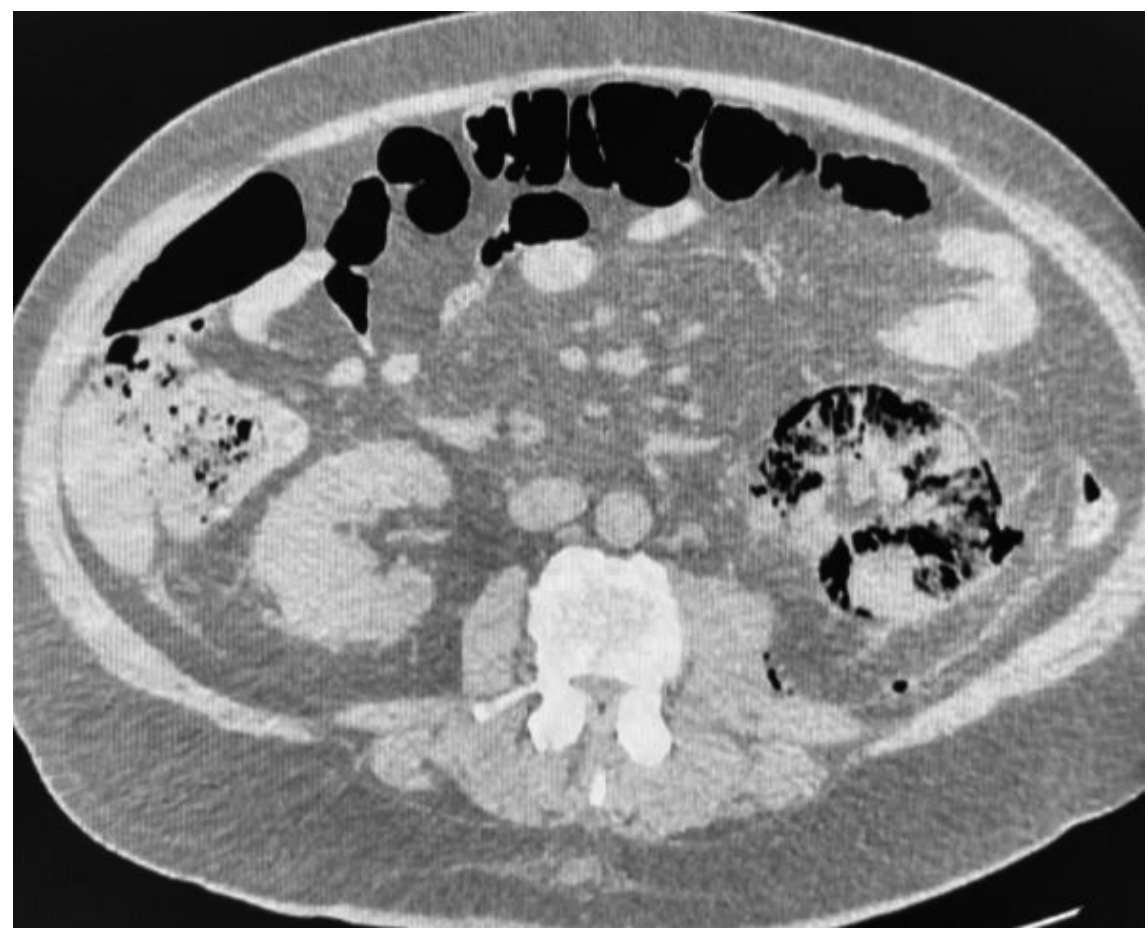

Fig. 3. MSCT. 12.14.2020. The left kidney with a large number of air bubbles, the parenchyma is not differentiated. 

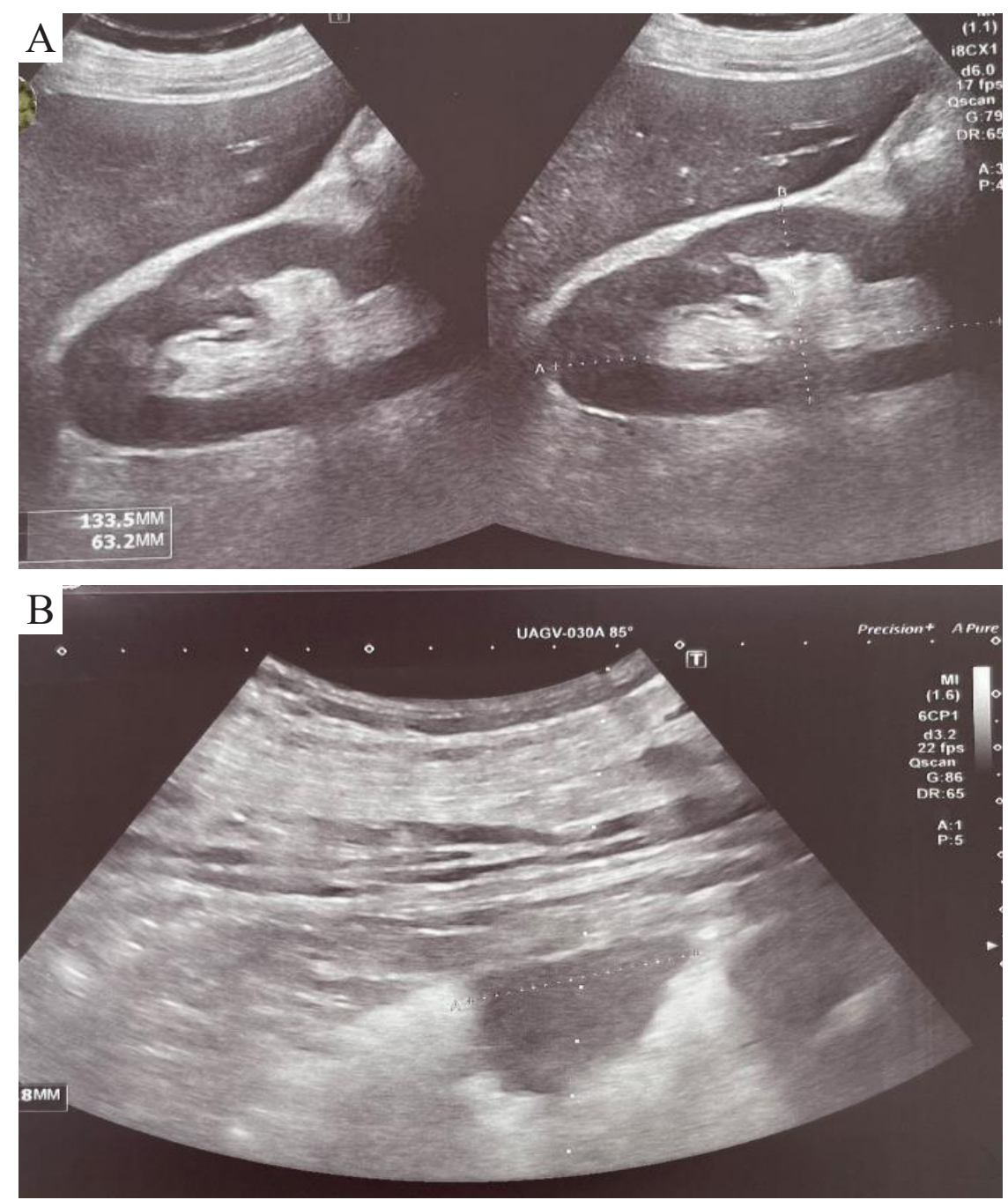

Fig. 4. US. A - right kidney; B - left kidney is not visualized, liquid collector is in its place.

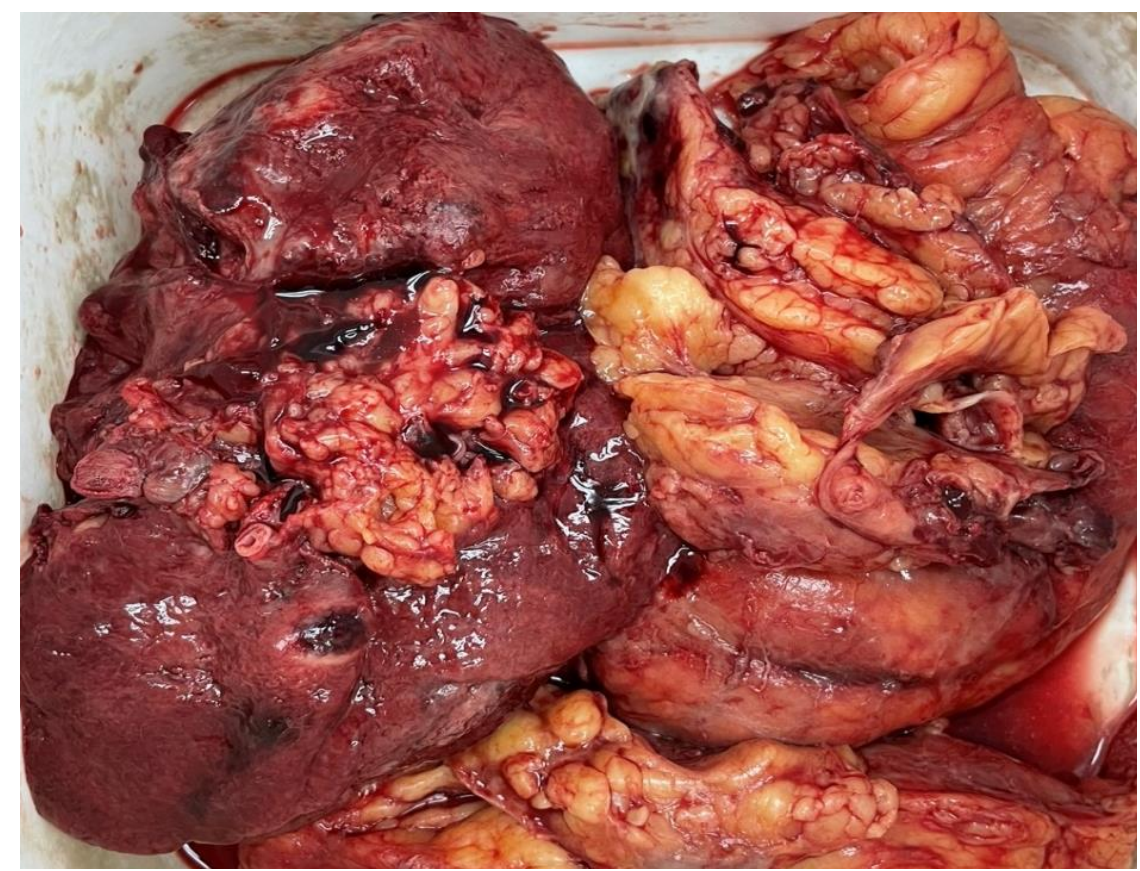

Fig. 5. Macro-specimen of the removed left kidney with pronounced signs of EP. 
Mortality (\%) of COVID-19 patients with concomitant diseases [6].

\begin{tabular}{|l|c|c|c|}
\hline \multirow{2}{*}{\multicolumn{1}{c|}{ Disease }} & \multicolumn{3}{c|}{ Countries } \\
\cline { 2 - 4 } & China & Italy & USA \\
\hline Arterial hypertension & 9,5 & 73,8 & 58,0 \\
\hline Diabetes & 7,4 & 35,5 & 4,0 \\
\hline COPD & 7,0 & 13,7 & 9,0 \\
\hline CVD & 7,3 & 42,5 & 0,6 \\
\hline Liver disease & 2,4 & 3,7 & 55,0 \\
\hline Obesity & 13,0 & 8,5 & 21,0 \\
\hline Kidney disease & 0,7 & 20,2 & 9,5 \\
\hline Malignant tumors & 2,0 & 5,0 & \\
\hline
\end{tabular}

Abbreviations: COPD - chronic obstructive pulmonary disease; CVD-cardiovascular diseases.

\section{Conclusion}

A clinical observation of a 66-year-old patient with EP of the left kidney, initiated by oxygen-dependent severe Covid pneumonia, is described. CT and US are recommended to identify EP, and early nephrectomy is considered the treatment of choice, especially in the patient with poor prognosis. If not recognized and treated in time, the clinical course of Covid-modulated EPO can be life-threatening.

Conflict of interest information. The author declares no conflicts of interest related to the publication of this article.

\section{Literature}

1. Новинский А. А. Эмфизематозный пиелонефрит: эпидемиология, современные подходы к диагностике и лечению / А. А. Новинский, А. Ф. Зинухов // Эксп. и клин. урология. -2020. № 5. - С. 100-105.

2. Руднев А. О. КТ-диагностика эмфизематозного пиелонефрита у больной сахарным диабетом / А .О. Руднев, М. Н. Максим, Н. М. Ковылина // Вестник РУДН. Серия: Медицина. - 2016. - № 1. - С. 161-165.

3. Христенко Е. А. КТ-паттерны при COVID-19 ассоциированных пневмониях стандартизация описаний исследований на основе глоссария общества Флейшнера / Е. А.Христенко, О. фон Стакельберг, Х.-У. Кауцор // REJR. - 2020. - 10(1). - C. 16-26. https://doi. org/10.21569/2222-7415-2020-10-1-16-26.
4. Aboumarzouk O. M. Emphysematous pyelonephritis: Time for a management plan with an evidence-based approach / O. M. Aboumarzouk, O. Hughes, K. Narahari // Arab. J Urol. - 2014. Vol. 12(2). - P. 106-115. https://doi.org/10.1016/j. aju.2013.09.005.

5. Bamanikar A. Fever with abdominal pain and diabetes - Is it Emphysematous Pyelonephritis? / A. Bamanikar, S. Dhobale // Malays J Med Sci. 2014. - Vol. 21(3). - P.85-88.

6. Ejaz H. COVID-19 and comorbidities: Deleterious impact on infected patients / H. Ejaz, A. Alsrhani, A. Zafar // Journal of Infection and Public Health. - 2020. - Vol. 13(12). - P. 1833-1839. https://doi.org/10.1016/j.jiph.2020.07.014.

7. Kelly H.A. Pneumaturia / H. A. Kelly, W. G. MacCullem // JAMA. - 1898. - Vol. 31(8). - P. 375-381. https://doi.org/10.1001/ jama.1898.92450080001001.

8. Krol B. C. A rare case of emphysematous pyelonephritis caused by Candida parapsilosis and Finegoldia magna complicated by medical care avoidance / B. C. Krol, A. K. Hemal, E. M. Fenu // CEN Case Rep. - 2021. - Vol. 10. - P. 111-114. https://doi.org/10.1007/s13730-020-00531-4.

9. Kulchenko N. G. Epidemiology of kidney disease in patients with COVID-19 / Kulchenko N. G. // Research and Practical Medicine Journal. 2020. - Vol. 7(3). - P. 74-82. (In Russ.) https://doi. org/10.17709/2409-2231-2020-7-3-7.

10. Lin L. Hypothesis for potential pathogenesis of SARS-CoV-2 infection - a review of immune changes in patients with viral pneumonia / L. Lin // Emerg. Microbes Infect. - 2020. - N 9. - P. 727-732. 
11. Naicker S. The novel coronavirus 2019 epidemic and kidneys / S. Naicker, C. W. Yang, S. J. Hwang // Kidney Int. - 2020. - Vol. 97(5). - P. 824828. https://doi.org/10.1016/j.kint.2020.03.001.

12. Schultz E. H. Emphysematous pyelonephritis / E. H. Schultz, E. H. Klorfein // J Urol. - 1962. - Vol. 87. - P. 762-766. https://doi.org/10.1016/ S0090-4295(96)00501-8.

13. Ubee S. S. Emphysematous pyelonephritis / S. S. Ubee, L. McGlynn, M. Fordham // BJU International. - 2011. - Vol. 107. - P. 1474-1478. https:// doi.org/10.1111/j.1464-410X.2010.09660.x.

14. Wan Y. L. Acute gas-producing bacterial renal infection: correlation between imaging findings and clinical outcome / Y. L. Wan, T. Y. Lee, M. J. Bullard // Radiology. - 1996. - Vol. 198(2). - P. 433-438. https://doi.org/10.1148/radiology.198.2.8596845.

15. Zou X. Single-cell RNA-seq data analysis on the receptor ACE2 expression reveals the potential risk of different human organs vulnerable to 2019nCoV infection / X. Zou, K. Chen, J. Zou // Front Med. - 2020. - Vol. 14(2). - P. 185-192. https://doi. org/10.1007/s11684-020-0754-0.

\section{COVID-MODULATED \\ EMPHYSEMATOUS PYELONEPHRITIS AGAINST THE BACKGROUND OF A SEVERE COURSE OF OXYGEN-DEPENDENT COVID PNEUMONIA}

\section{A.I. Mukhomor, A.I. Zhelezko}

EP is a rare form of acute purulent pyelonephritis caused by microorganisms that decompose glucose into acid and carbon dioxide, characterized by the development of an acute necrotizing process in the renal parenchyma. The disease is characterized by the accumulation of gas bubbles in the kidney tissues (in the kidney interstitium, its cavity or urinary system) and in the surrounding fiber. The disease is characterized by the accumulation of gas bubbles in the kidney tissues (in the kidney interstitium, its cavity or urinary system) and in the surrounding fiber.

A clinical observation of a 66-year-old patient with emphysematous pyelonephritis of the left kidney, initiated by oxygen-dependent severe Covid pneumonia, is described. The comments in- dicate the possible pathogenesis of the pathology and the role of polymorbidity.

\section{КОВІД-МОДУЛЬОВАНИЙ ЕМФІЗЕМАТОЗНИЙ ПІЕЛОНЕФРИТ НА ТЛІ ВАЖКОГО ПЕРЕБІГУ КИСЕНЬ-ЗАЛЕЖНОЮ КОВЦДНОЙ ПНЕВМОНIÏ}

\section{O.I. Мухомор, O.I. Железко}

Емфізематозний пієлонефрит - рідкісна форма гострого гнійного пієлонефриту, що викликається мікроорганізмами, які розкладають глюкозу на кислоту і вуглекислий газ, що характеризується розвитком гострого некротизуючого процесу в нирковій паренхімі. Захворювання характеризується накопиченням бульбашок газу в тканинах нирки (в інтерстиції нирки, порожнинної або сечовивідної їі системі) і в навколишній клітковині.

Описано клінічний нагляд хворого 66 років 3 емфізематозним пієлонефритом лівої нирки, ініційованим кисень-залежною ковідною пневмонією важкого перебігу. У коментарях вказано можливий патогенез патології і роль поліморбідності.

\section{КОВИД-МОДУЛИРОВАННЫЙ ЭМФИЗЕМАТОЗНЫЙ ПИЕЛОНЕФРИТ НА ФОНЕ ТЯЖЕЛОГО ТЕЧЕНИЯ КИСЛОРОД-ЗАВИСИМОЙ КОВИДНОЙ ПНЕВМОНИИ}

\section{А.И. Мухомор, А.И. Железко}

Эмфизематозный пиелонефрит - редкая форма острого гнойного пиелонефрита, вызываемая микроорганизмами, разлагающими глюкозу на кислоту и углекислый газ, характеризующаяся развитием острого некротизирующего процесса в почечной паренхиме. Заболевание характеризуется накоплением пузырьков газа в тканях почки (в интерстиции почки, полостной или мочевыводящей её системе) и в окружающей клетчатке. Описано клиническое наблюдение больного 66 лет с эмфизематозным пиелонефритом левой почки, инициированным кислород-зависимой ковидной пневмонии тяжёлого течения. В комментариях указан возможный патогенез патологии и роль полиморбидности. 